\title{
PROGRAM PENGEMBANGAN DESA MITRA DI KIAMA KABUPATEN TALAUD: INSTALASI POMPA AIR TENAGA SURYA
}

\author{
Meita Rumbayan ${ }^{1 *}$, Sherwin R.U. Sompie ${ }^{2}$, Rilya Rumbayan ${ }^{3}$ \\ 1,2 Fakultas Teknik, Universitas Sam Ratulangi \\ 3Jurusan Teknik Sipil, Politeknik Manado \\ Email: 1meitarumbayan@unsrat.ac.id; 2aldo@unsrat.ac.id; 3rilya.rumbayan@gmail.com \\ *Penulis korepondensi
}

\begin{abstract}
Abstrak: Pengabdian kepada masyarakat ini bertujuan untuk menerapkan teknologi kemandirian penyediaan tenaga listrik berbasis sumber energi terbarukan yang tersedia secara lokal. Teknologi ini diterapkan di Desa Kiama yang terletak di pulau terpencil Talaud. Permasalahan keterbatasan akses listrik telah dihadapi oleh masyarakat pesisir di Pulau Talaud. Pompa air yang disuplai tenaga surya merupakan teknologi yang paling cocok diterapkan di daerah yang akses jaringan listriknya terbatas. Metode pelaksanaan program pengembangan desa mitra ini terdiri dari beberapa tahapan, yaitu: (1) Penerapan teknologi tepat guna pompa air tenaga surya untuk mensuplai tangki air; (2) Alih teknologi berbasis pemanfaatan energi terbarukan untuk meningkatkan pengetahuan dan keterampilan masyarakat di desa terpencil. Manfaat kegiatan ini adalah meningkatkan pengetahuan masyarakat terhadap pemanfaatan energi terbarukan dan meningkatkan taraf hidup masyarakat terhadap akses listrik secara mandiri. Implementasi program ini adalah merancang dan membangun pompa air bertenaga teknologi tenaga surya dan pemasangan satu unit teknologi tersebut pada sebuah gereja di desa Kiama. Hasil yang diperoleh dari kegiatan ini adalah peningkatan kesejahteraan dan kenyamanan hidup masyarakat karena akses listrik.
\end{abstract}

Kata kunci: Pengabdian masyarakat, Desa Kiama, pulau terpencil, energi terbarukan, pompa air tenaga surya

\begin{abstract}
This community service aims to apply the technology of independence supply electricity based on renewable source of energy that is available locally. This technology is applied in Kiama village that is located in the remote island of Talaud. The problems regarding the limited access of electricity have been faced by the coastal community in Talaud Island. The water pump supplied by solar energy is the most suitable technology to be applied in the area that has limited access to electricity grid. The method of implementing this partner village development program consists of several stages, namely: (1) Application of suitable technology for solar water pump to supply water tank; (2) Transfer technology based on renewable energy utilization to increase knowledge and skills for the community in the remote village. The beneficial aspect of this activity is to improve the knowledge of society toward the renewable energy utilization and to improve of community standard lives toward the access of electricity, independently. The program implementations were designed and built-up of water pump powered by solar energy technology and the one unit installation of the technology to a church in the Kiama village. The results obtained from this activity are improvement of the welfare and the comfort of people's lives due to access to electricity. Regarding appropriate technology applied for the remote communities.
\end{abstract}

Keywords: Community service, Kiama Village, remote island, renewable energy, solar water pump.

\section{PENDAHULUAN}

Energi listrik sudah menjadi kebutuhan hidup masyarakat di berbagai kegiatan sehari-hari. Masyarakat pesisir di kepulauan Talaud menghadapi keterbatasan akses ketersediaan listrik yang tidak bisa disuplai 24 jam dari jaringan PLN.
Krisis energi listrik ini merupakan masalah yang penting untuk dicari solusinya bagi masyarakat pesisir di daerah perbatasan di desa Kiama yang berlokasi di Kabupaten Kepulauan Talaud. Peta lokasi pulau Talaud yang merupakan pulau terluar yang terletak di daerah perbatasan ditunjukan pada Gambar 1. 


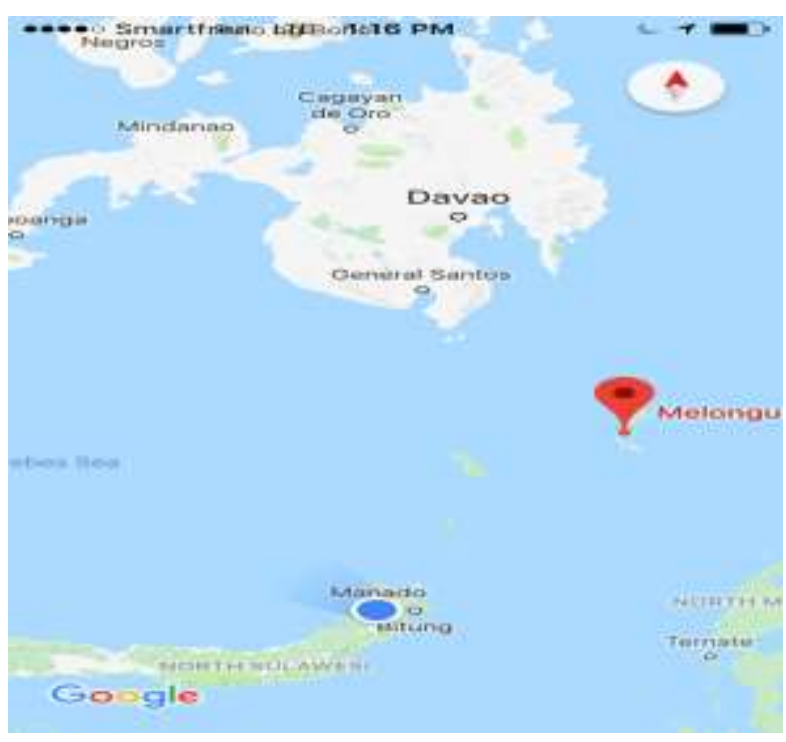

Gambar 1. Peta lokasi pulau Talaud yang merupakan pulau terluar yang terletak di daerah perbatasan (Sumber: www.google.com)

Tujuan kegiatan pengabdian masyarakat ini secara umum adalah lanjutan pelaksanaan Program Pengembangan Desa Mitra (PPDM) di Desa Kiama yang mengalami masalah keterbatasan suplai listrik dari jaringan PLN (https://www.indobrita.co/2019/09/09/desa-kiama-jadi-sentra-sciencetechno-park-energi-terbarukan-dan-rumah-tahangempa/diakses 9 September 2019). Secara khusus, tujuan kegiatan ini adalah penerapan Teknologi Tepat Guna (TTG) berbasis energi terbarukan berupa alat cuci tangan dengan tenaga pompa air tenaga surya sebagai salah satu solusi dalam menjawab masalah krisis listrik di desa Kiama yang terletak di Kabupaten Kepulauan Talaud yang merupakan perbatasan antara Filipina dan Indonesia.

Kabupaten Kepulauan Talaud secara administratif termasuk ke dalam wilayah Provinsi Sulawesi Utara dengan Melonguane sebagai Ibukota Kabupaten. Adapun jarak antara ibukota kabupaten yaitu Melonguane dan ibukota Provinsi Sulawesi Utara yaitu Manado adalah 271 mil laut. Kabupaten Kepulauan Talaud merupakan salah satu wilayah kabupaten yang memiliki karakteristik berciri kepulauan, perbatasan, tertinggal/ terisolasi dan daerah rawan bencana (http://skptalaud.blogspot.co.id/2017/07/tentang-talaud.html, diakses 10 Agustus 2020).

Kegiatan PPDM ini merupakan program pengabdian masyarakat multitahun di Desa Kiama untuk mewujudkan introduksi teknologi Energi Terbarukan di desa Kiama. Hasil penerapan ilmu pengetahuan dan teknologi yang sudah diimplementasikan pada desa mitra di Desa Kiama Kepulauan Talaud pada tahun sebelumnya adalah sistem pembangkit tenaga listrik mandiri berbasis energi terbarukan bersumber pada potensi desa yang ada berupa penerangan jalan umum menggunakan tenaga surya. Hasil kegiatan PPDM tahun sebelumnya berupa penerapan TTG berupa penerangan tenaga surya oleh tim pelaksana di Desa Kiama sudah dipublikasikan pada seminar pengabdian masyarakat di Politeknik Ujung Pandang (Rumbayan dkk, 2019). Jejak pelaksanaan pengabdian masyarakat yang sudah dipublikasikan tim pelaksana sebelumnya ada dalam jurnal Penelitian dan Pengabdian Ethos (Sains \& Teknologi) dengan judul "Introduksi Teknologi Biogas Sebagai Energi Terbarukan untuk Masyarakat Pedesaan" (Rumbayan, 2017) dan "Penerapan Pembangkit Listrik Tenaga Surya Skala Rumah Sederhana di Desa Lahopang Kabupaten Sitaro Provinsi Sulawesi Utara" (Rumbayan, 2018).

\section{METODE PELAKSANAAN}

Metode pelaksanaan kegiatan pengabdian masyarakat ini terdiri dari beberapa tahap, yaitu: (1) Penerapan teknologi tepat guna berbasis terbarukan berupa instalasi pompa air tenaga surya untuk peningkatan kesejahteraan dan kenyamanan hidup masyarakat akibat adanya akses listrik secara mandiri; (2) Pelatihan tentang pengoperasian dan perawatan untuk peningkatan pengetahuan dan ketrampilan mengenai teknologi tepat guna yang diterapkan. Namun pada penulisan artikel ini penulis mengulas pada tahap awal tentang penerapan TTG yang sudah dilaksanakan, sedangkan tahap pelatihan operasi dan perawatan masih merupakan rencana selanjutnya sehingga ditulis pada bagian rekomendasi.

Proses pelaksanaan kegiatan pengabdian masyarakat di Desa Kiama Kabupaten Kepulauan Talaud digambarkan seperti pada Gambar 2.

Persiapan \& Sosialisasi Kegiatan Pengabdian Masyarakat:

1. Observasi lapangan di desa Mitra

2. Survey Data untuk Identifikasi Masalah

3. Wawancara untuk Analisis Situasi Mitra

Focus Group Discussion Tim Pelaksana dan Mitra untuk solusi listrik mandiri pompa air tenaga surya sebagai suplai listrik mandiri untuk alat cuci tangan di desa Kiama kepulauan Talaud.

Pelaksanaan Kegiatan Pengabdian Masyarakat:

1. Rancang bangun teknologi sistem listrik mandiri bersumber dari energi tenaga surya untuk pompa air sebagai suplai dari sumur ke alat cuci tangan di lokasi mitra.

2. Pendampingan dan pelatihan pengoperasian dan perawatan TTG yang diterapkan ke masyarakat melalui kegiatan dalam jaringan (daring) oleh tim pelaksana dan secara pertemuan langsung oleh mahasiswa dan alumni yang berdomisili di lokasi mitra.

Gambar 2. Pelaksanaan Kegiatan Pengabdian Masyarakat 
Secara rinci, metode pelaksanaan kegiatan pengabdian masyarakat di desa Kiama ini diuraikan sebagai berikut:

1. Identifikasi kebutuhan masyarakat

Identifikasi kebutuhan masyarakat dilakukan melalui metode survey dan diskusi kelompk terfokus atau focus group discussion. Melalui survey dan wawancara langsung ke desa Kiama oleh mahasiswa penduduk lokal, teridentifikasi kebutuhan masyarakat mitra yang mengalami masalah keterbatasan jaringan listrik dan masalah suplai air bersih yang tergantung listrik PLN namun sering terjadi pemadaman, padahal pasokan air bersih sangat dibutuhkan untuk kebutuhan sehari-hari terutama masa pandemi COVID-19 yang memerlukan alat cuci tangan dalam penanganan pencegahan wabah.

2. Perancangan Program untuk Penerapan TTG ke masyarakat

Perancangan teknologi berupa alat cuci tangan dengan tenagalistrik mandiri dari pompa air tenaga surya menjadi solusi yang ditawarkan untuk menjawab kebutuhan listrik dan air bersih untuk kelompok masyarakat pesisir di desa Kiama Kabupaten Kepulauan Talaud. Perancangan TTG diberikan pada Gambar 3.

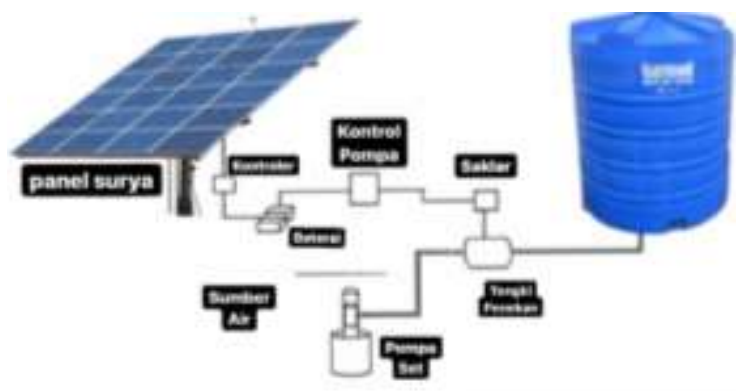

Gambar 3. Perancangan Teknologi Energi Terbarukan yang diterapkan ke Masyarakat berupa Alat Cuci Tangan dengan Sumber Tenaga Listrik mandiri dari Panel Surya

3. Pembuatan Produk TTG Alat Cuci Tangan dengan Pompa Air Tenaga Surya.

Pembuatan teknologi berupa alat cuci tangan dengan pompa air bersumber dari tenaga surya dirakit dan diinstal di lokasi yang direkomendasi mitra yaitu fasilitas umum tempat ibadah gereja di desa Kiama.

4. Pengoperasian alat TTG berbasis energi terbarukan di Desa Kiama.

Pengoperasian TTG berupa 1 unit pompa air tenaga surya diterapkan di lapangan pada lingkungan masyarakat pesisir desa Kiama di Kabupaten Kepulauan Talaud

5. Pendampingan operasional berupa pelatihan operasi dan perawatan TTG

Pendampingan operasional teknologi penerangan dan pompa air tenaga surya akan dilakukan
Tim pelaksana berupa penyuluhan dan bimbingan teknis tentang operasi dan perawatan TTG yang diterapkan.

\section{HASIL DAN PEMBAHASAN}

Melalui kegiatan pengabdian masyarakat di Desa Kiama kabupaten Kepulauan Talaud ini sudah dilakukan penerapan teknologi tepat guna berbasis energi terbarukan berupa pompa air tenaga surya sebagai alat untuk mengalirkan air dari sumur ke tong penampung untuk keperluan cuci tangan masyarakat di tempat ibadah rumah gereja. Gambar 4, 5, 6, 7 dan 8 menunjukan proses pemasangan tong air, penyambungan pipa, pemasangan pompa air dan pemasangan kontroler pada kotak panel listrik dan pemasangan panel surya di atap sebagai sumber energi listrik.

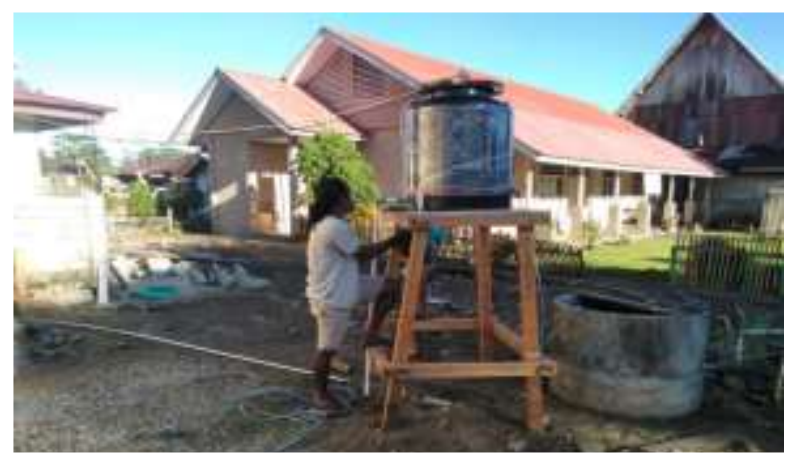

Gambar 4. Proses pemasangan tong air

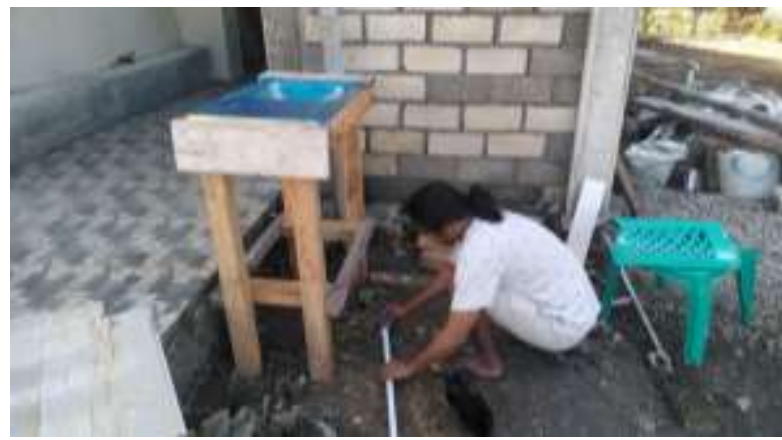

Gambar 5. Proses penyambungan pipa

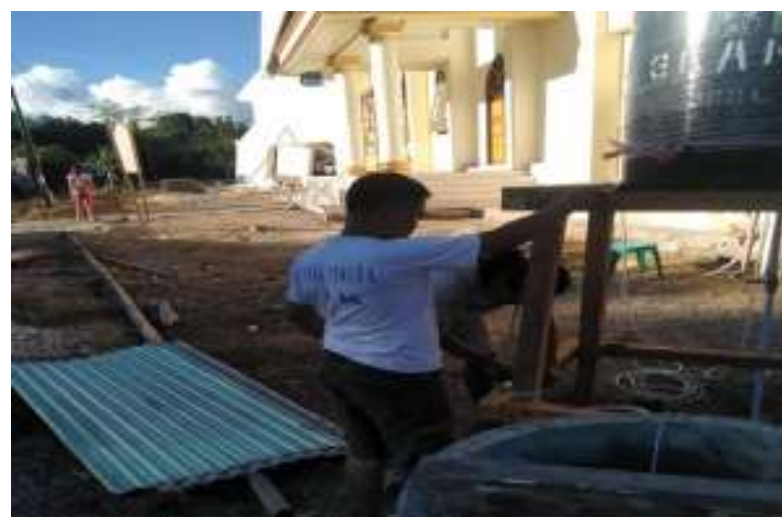

Gambar 6. Proses pemasangan pompa air tenaga surya 


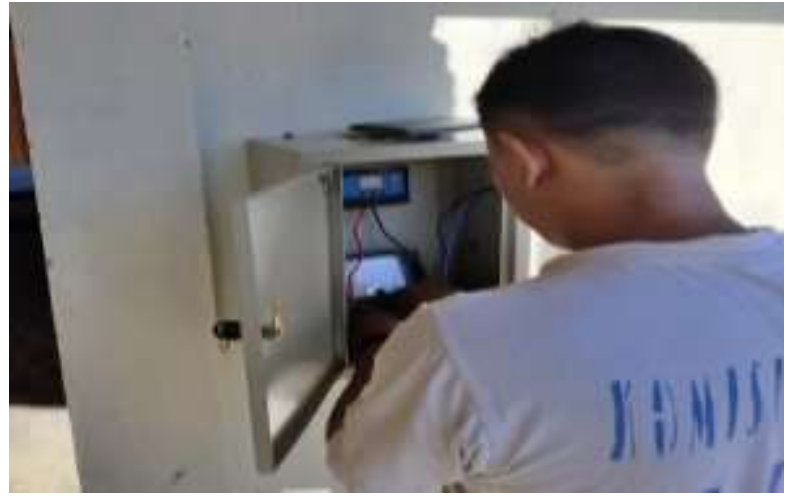

Gambar 7. Proses pemasangan kontroler pada kotak panel listrik

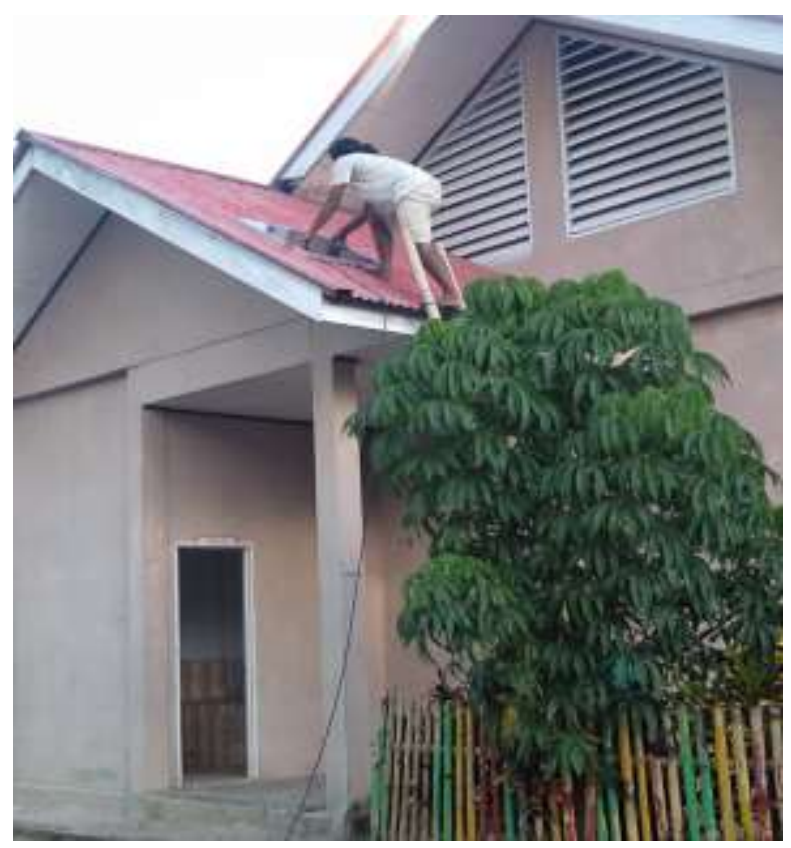

Gambar 8. Proses pemasangan panel surya di atap sebagai sumber energi listrik

Respon atau tanggapan mitra terhadap kegiatan pengabdian masyarakat di Desa Kiama ini adalah sangat mendukung pelaksanaan program pengembangan desa mitra ini. Salah satu kegiatan pengenalan dan penerapan teknologi tepat guna berbasis energi terbarukan di Desa Kiama ini yaitu instalasi pompa air tenaga surya untuk mengalirkan air dari sumur ke tong penampungan untuk cuci tangan. Penerapan TTG ini mendapat respon positif dari masyarakat pengguna dikarenakan alat ini sangat berguna dalam usaha pencegahan dan penanganan pandemi COVID-19. Gambar 4-8 menunjukan proses penerapan TTG berupa penerapan alat cuci tangan yang dengan pompa air tenaga surya sebagai sumber listrik yang berlokasi di haaman gereja dan sekolah yang menunjang protokol kesehatan mencuci tangan untuk masyarakat mitra. Hasil penerapan teknologi tepat guna di Desa Kiama Kabupaten Kepulauan Talaud diberikan pada Gambar 9.



Gambar 9. Hasil penerapan TTG berupa alat cuci tangan dengan pompa air tenaga surya yang dinikmati oleh masyarakat mitra di Desa Kiama Kepulauan Talaud

\section{SIMPULAN}

Karena terbatasnya akses listrik dari jaringan PLN di daerah perbatasan ini, teknologi tepat guna yang berupa listrik mandiri dari sumber tenaga matahari menjadi solusi untuk cadangan penyediaan tenaga listrik. Penerapan teknologi tepat guna berupa pompa air tenaga surya di desa mitra yaitu Desa Kiama yang terletak di pulau perbatasan sangat cocok sebagai solusi inovasi dari masalah keterbatasan akses listrik.

Keberlanjutan kegiatan TTG untuk pemeliharaan alat dapat dilakukan berupa pelatihan secara tatap muka dan atau secara dalam jaringan (daring). Secara tatap muka dapat dilakukan oleh mahasiswa atau alumni yang tinggal di daerah Kepulauan Talaud dengan memberi pelatihan kepada masyarakat secara langsung tapi dengan protocol kesehatan daam rangka pencegahan pandemi COVID-19 yaitu memakai masker, menjaga jarak dan mencuci tangan. Selain itu karena jarak tempuh yang jauh dari tempat tim pelaksana bisa juga melakukan transfer teknologi dalam jaringan melalui pelatihan online kepada warga masyarakat di Desa Kiama Kabupaten Kepulauan Talaud.

\section{UCAPAN TERIMAKASIH}

Ucapan terima kasih kepada Direktorat Riset dan Pengabdian Masyarakat (DRPM) Kementerian Riset dan Teknologi/BRIN untuk hibah yang diberikan sehingga kegiatan PPDM di Desa Kiama Kepulauan Talaud ini dapat dilaksanakan, juga kepada Lembaga Penelitian dan Pengabdian Kepada Masyarakat (LPPM) Universitas Sam Ratulangi Manado untuk dukungan dalam pelaksanaan kegiatan PPDM.

\section{DAFTAR PUSTAKA}

Rumbayan, M., Tangkuman, S., dan Sompie, S. 2018. Penerapan Pembangkit Listrik Tenaga Surya Skala Rumah Sederhana di Desa Lahopang Kabupaten Sitaro Provinsi Sulawesi 
Utara, Ethos (Jurnal Penelitian dan Pengabdian), Vol. 6 no 1, Unisba, Bandung, Indonesia. Rumbayan, M., Sompie, S dan Rumbayan, R. 2019. Program Pengembangan Desa Mitra di Kiama Kabupaten Talaud: Penerapan Teknologi Tepat Guna Penerangan Listrik Energi Terbarukan dan Rumah Tahan Gempa, Seminar Nasional Hasil Penelitian dan Pengabdian Kepada Masyarakat 2019, Politeknik Ujungpandang, Indonesia. Hal. 415-420.
Rumbayan, M. 2017. Introduksi Teknologi Biogas Sebagai Energi Terbarukan untuk Masyarakat Pedesaan, Ethos (Jurnal Penelitian dan Pengabdian), Vol. 6 no 1, Unisba, Bandung, Indonesia.

https://www.indobrita.co/2019/09/09/desa-kiamajadi-sentra-science-techno-park-energiterbarukan-dan-rumah-tahan-gempa/ diakses 9 September 2019.

http://skptalaud.blogspot.co.id/2017/07/tentangtalaud.html, diakses 10 Agustus 2020. 